\title{
Acinetobacter calcoaceticus SJ19 and Bacillus safensis SJ4, two Algerian rhizobacteria protecting tomato plants against Botrytis cinerea and promoting their growth
}

\author{
Abdelhamid Foughalia ${ }^{1,2,3,4^{*}} \mathbb{1}$, Yousra Bouaoud ${ }^{3}$, Charlotte Chandeysson ${ }^{4}$, Mawahib Djedidi ${ }^{2}$, \\ Mohamed Tahirine ${ }^{2}$, Kamel Aissat ${ }^{3,5}$ and Philippe Nicot ${ }^{4 *}$
}

\begin{abstract}
Background: Botrytis cinerea, the causal agent of grey mould, is a polyphagous fungus that infects a wide range of plants, including tomato. In many countries, including Algeria, the management of grey mould is a challenging problem, even with chemical control. This necessitates the search for other strategies. The objective of this study was to evaluate the biocontrol potential of two rhizospheric bacterial isolates for the protection of tomato against $B$. cinerea.

Results: On tomato plants, the two bacterial isolates consistently provided high levels of protection (on average $72.1 \%$ for SJ19 and $52.3 \%$ for SJ4). Their applications as a 1:1 mixture reinforced their effect (87.8\% protection), indicating their compatibility and a potential use as a consortium. In vitro, the isolates significantly inhibited the mycelial growth of B. cinerea strains, both through direct confrontation in dual-culture assays (12-69\% inhibition) and through the production of volatile compounds (36-46\% inhibition). The two isolates, applied as seed treatment and as drench on seedlings, also showed strong growth-promoting effects on tomatoes. They substantially increased the length and fresh weight of shoots and roots, as well as stem diameter, leaf number and chlorophyll content, compared to untreated plants.
\end{abstract}

Conclusion: The two bacteria tested in this study showed a high potential for use as biostimulants and as biofungicides against tomato grey mould.

Keywords: Biocontrol, PGPR, Botrytis cinerea, Acinetobacter calcoaceticus, Bacillus safensis, Tomato, Algeria

\section{Background}

Tomato grey mould caused by Botrytis cinerea Pers (anamorph of Botryotinia fuckeliana (de Bary) Whetzel) is becoming one of the most serious concerns in Algeria's unheated greenhouses (Aissat et al. 2008). This necrotrophic and polyphagous fungus can attack the tomato's

\footnotetext{
*Correspondence: hmadou.fou@gmail.com; philippe.nicot@inrae.fr 'Laboratoire de Génétique, Biotechnologie et Valorisation des Bio-Ressources (GBVB), Faculté des Sciences Exactes et des Sciences de la Nature et de la Vie, Université Mohamed Khider, Biskra, Algeria

${ }^{4}$ Plant Pathology, INRAE, 84140 Montfavet, France

Full list of author information is available at the end of the article
}

aerial parts, causing symptoms such as concentric spots on the leaves, lesions and stem cankers. Fruits, whether pre- or post-harvest, have been known to be affected by this disease. The most well-known symptoms on tomato fruits are "ghost spots" (Panno et al. 2021). Algerian farmers in the coastal districts, such as Bejaia and Jijel, are accustomed to installing their greenhouses close to the sea, which results in particularly humid conditions. Under these conditions, several fungal diseases like grey mould become a challenging problem to manage (Aissat et al. 2008). 
In fact, to manage this disease, which is responsible for significant annual losses around the world, farmers often rely on chemical fungicides, which are viewed as the most effective tool to control this disease (Panno et al. 2021). A common practice was to spray the aerial parts of plants as a preventative strategy before the disease was observed (Liu et al. 2021). However, this type of control has been associated with a number of issues all over the world. It has been demonstrated that $B$. cinerea, due to its genetic variability, can develop resistance to a variety of commonly used chemical fungicides (Liu et al. 2021). Undesirable side effects of pesticides have increasingly generated concerns about possible public health and environmental issues. All of these limitations have prompted researchers and agronomists to seek out alternate strategies of disease and pest management (Walia et al. 2021). Biological control has increasingly been used in various countries as a key tool for these new control strategies. It entails the use of either living (such as microorganisms) or natural products, such as plant extracts and essential oils derived from natural sources (Panno et al. 2021). Currently, however, no microbial bio-fungicide is authorized for agricultural use in Algeria (Anonymous 2017). In this context, this study was initiated with the objective of evaluating biocontrol potential of two indigenous rhizobacteria, applied singly or in combination, for the protection of tomato against $B$. cinerea. Their ability to promote plant growth was also assessed.

\section{Methods}

\section{Bacterial isolates}

The two bacterial isolates used in this study (SJ4 and SJ19) were isolated in 2018 from the rhizospheric soil of healthy tomato plants cultivated in unheated greenhouses near Jijel, Algeria. Isolation, purification and storage were performed according to Akter et al. (2015). Their identification was carried out on the basis of their molecular characterization. For this, their DNA was extracted and the amplification of the 16S rDNA was carried out using the universal primers $\mathrm{fd} 1$ and S17 as described by Bouaoud et al. (2018). The PCR results were sent for sequencing. The NCBI database (https:// www.ncbi.nlm.nih.gov) and the EzBioCloud platform (https://www.ezbiocloud.net) were used to compare the sequences and determine the species. Based on this analysis, the bacterial isolates SJ4 and SJ19 were assigned, respectively, to the species Bacillus safensis (GenBank accession number: OK562384) with $100 \%$ of similitude and to Acinetobacter calcoaceticus (GenBank accession number: OK562383) with $99 \%$ of similitude.

\section{Botrytis cinerea strains}

Five strains of $B$. cinerea were used in this study. Four strains (BCJ1, BCJ2, $\mathrm{BCJ} 3$ and $\mathrm{BCJ} 4)$ were isolated in the Jijel District from tomato plants cultivated in unheated greenhouses and exhibiting grey mould symptoms. Strain BC21 was provided by the Mycology Laboratory of INRAE Avignon, France. All the strains were stored at $-20{ }^{\circ} \mathrm{C}$. For revivification, culture and inoculum production, PDA medium (Difco Laboratory Detroit, USA) was used according to Bouaoud et al. (2018).

\section{Tomato plants}

Tomato plants (variety Clodano; Syngenta Seeds, Switzerland) were grown in individual pots in a heated greenhouse and used 6 weeks after sowing, for in planta biocontrol assays.

\section{In vitro antagonistic effect of the bacteria against Botrytis cinerea}

\section{Direct confrontation}

To evaluate the direct in vitro antagonistic effect against five strains of $B$. cinerea, the bacterial isolates were placed in contact with the fungal pathogen on the surface of PDA medium (dual culture assay) as described by $\mathrm{Xu}$ and Kim (2014). Petri dishes containing only the fungus without bacteria were prepared in parallel with the other plates. After $72 \mathrm{~h}$ of incubation at $22{ }^{\circ} \mathrm{C}$, the percentage of mycelial growth inhibition was calculated according to Whipps (1987). Three plates were used per bacterial isolate, and the experiment was repeated three times independently.

\section{Indirect confrontation}

The two bacteria were assessed for their ability to produce volatile antifungal compounds according to the protocol described by Barakat et al. (2014). Strain BC21 of $B$. cinerea was used in these tests. To determine the percentage of mycelial growth inhibition, control plates without the bacteria were prepared and incubated together with the other plates at $22{ }^{\circ} \mathrm{C}$ for $72 \mathrm{~h}$. Three plates were used per bacterium, and three independent repetitions of the whole experiment were carried out.

\section{In planta biocontrol assays}

To evaluate the in planta antagonistic activity of the two bacterial isolates against $B$. cinerea, 6-week old tomato plants were used. Two leaves were removed from each plant, and the wounds were inoculated using 10- $\mu \mathrm{l}$ aliquots of a spore suspension of $B$. cinerea (strain $\mathrm{BC} 21)$ at $10^{6} \mathrm{spores} / \mathrm{ml}$. The wounds were then immediately treated either with a bacterial suspension $(10 \mu \mathrm{l}$ 
per wound; $10^{9} \mathrm{CFU} / \mathrm{ml}$ ) or left untreated as control plants. The two bacterial isolates were applied either singly, or in combination using a 1:1 (V/V) mixture of the cell suspensions. To evaluate a possible effect of the time of application of the bacteria on their protective efficacy, additional modalities were used consisting of plants with an application of the bacteria on the wounds either $1 \mathrm{~h}$ before or after the inoculation with B. cinerea. Thus, in total, the biocontrol assay entailed 10 modalities of treatments, and 5 replicated tomato plants were used per modality. The whole assay was carried out three times independently.

Following inoculation, all the plants were incubated in a growth chamber (14-h photoperiod; $22{ }^{\circ} \mathrm{C}$; $90 \%$ RH) for 7 days (Bouaoud et al. 2018). The development of disease from each inoculated wound was monitored by measuring the length of stem lesions between the $3^{\text {rd }}$ and the $7^{\text {th }}$ day after inoculation. Then, an area under the disease progress curve (AUDPC) was computed for each wound. The percentage of protection conferred by each bacterial isolate was assessed as follows: Protection $(\%)=100 \times\left(\right.$ average $\mathrm{AUDPC}_{\text {control }}$ - average $\left.\mathrm{AUDPC}_{\text {bacterial treatment }}\right)$ /average $\mathrm{AUDPC}_{\text {control }}$ (Decognet et al. 2009).

\section{Pathogenicity and induction of hypersensitive response (HR)}

In conjunction with the biocontrol assays described above, batches of tomato plants were used to evaluate a possible deleterious effect of the bacterial isolates. For this, leaves were removed from the plants as described above, but the wounds were not inoculated with $B$. cinerea. Instead, 10- $\mu \mathrm{l}$ aliquots of the bacterial suspensions were applied to the wounds and the plants were incubated in a growth chamber as described above. After 7 days of incubation, the wounds were examined for possible symptoms. Five plants were used for each bacterial isolate, and the whole experiment was carried out three times independently.

Another test was used to evaluate the ability of the two bacteria to induce a hypersensitivity response. Tobacco (Nicotiana tabacum) leaves were infiltrated with suspensions of the two bacterial isolates $\left(10^{9} \mathrm{CFU} / \mathrm{ml}\right)$ according to Morris et al. (2010). Control plants were infiltrated with a suspension of Pseudomonas syringae strain CC94 as a positive control, while plants infiltrated with sterile distilled water were used as a negative control. The plants were then incubated for $48 \mathrm{~h}$ in a growth chamber at $22{ }^{\circ} \mathrm{C}$ with a $14-\mathrm{h}$ photoperiod, and the plants were examined for possible necroses around the inoculation point, as a sign of hypersensitive response.

\section{Tomato growth promotion}

To assess the potential of the two bacteria to enhance tomato growth, tomato seeds (variety Clodano; Syngenta Seeds, Switzerland) were surface-sterilized by tipping its $3 \mathrm{~min}$ in $70 \%$ ethanol and $4 \mathrm{~min}$ in $0.9 \%$ (v/v) sodium hypochlorite solution. The seeds were then washed three times using sterile distilled water (Boukaya et al. 2018).

Batches of 25 seeds were then soaked for $2 \mathrm{~h}$ at room temperature in a suspension $\left(10^{9}\right.$ cells $\left./ \mathrm{ml}\right)$ of either SJ4 or SJ19. Control batches were soaked in sterile water. The seeds were then sown in sterile potting soil and placed in a heated glasshouse. Seven days after sowing, seed germination was assessed for each seed batch, and the seedlings were carefully uprooted and washed. Seedling growth was assessed, and a seed vigor index was computed according to Syed-Ab-Rahman et al. (2018) as the mean root length $\times$ percentage of seed germination. This assessment was carried out on 20 seedlings for each modality of seed treatment. The seven-day old seedlings were then transplanted to individual $(10 \times 15 \mathrm{~cm})$ pots containing a sterile potting soil and grown in the glasshouse. Five seedlings were transplanted for each modality of seed treatment. Two days after transplanting, each seedling received a drench treatment with $5 \mathrm{ml}$ of a similar bacterial suspension as the seed it had germinated from (drench with sterile distilled water for the control seedlings) (Mohamed et al. 2020). Four weeks after this treatment, the following morphometric parameters were measured on the plants: root and shoot lengths $(\mathrm{cm})$, stem diameter above the second leaf $(\mathrm{mm})$, number of leaves, and fresh weight of roots and shoots $(\mathrm{g})$. The chlorophyll content of the leaves was measured with the help of a portable chlorophyll meter (Konica Minolta SPAD 502). The whole experiment was carried out three times independently.

\section{Statistical analyses}

Analysis of variance (ANOVA) with post hoc test (Newman-Keuls multiple range test) was used to test the growth-promoting in vitro and in planta effects of the two bacterial isolates. However, a Mann-Whitney test was used to check the effect of the two bacterial strains on seed germination. Statistica (StatSoft Inc., Tulsa, USA) was used to conduct all the statistical analyses.

\section{Results \\ In vitro inhibition of Botrytis cinerea by the bacterial isolates \\ Direct confrontation}

In dual culture tests, both bacterial isolates significantly inhibited the mycelial growth of the five strains of $B$. cinerea (Table 1 and Fig. 1). With average inhibition rates 
Table 1 In vitro effect of two bacterial isolates against various Botrytis cinerea strains

\begin{tabular}{|c|c|c|c|c|c|c|c|c|}
\hline \multirow[t]{3}{*}{ Isolates } & \multirow[t]{3}{*}{ Bacterial species } & \multirow{3}{*}{$\begin{array}{l}\text { GenBank } \\
\text { accession } \\
\text { number }\end{array}$} & \multicolumn{6}{|c|}{ Mycelial Growth Inhibition (\%) $^{1}$} \\
\hline & & & \multicolumn{5}{|c|}{ Direct confrontation } & \multirow{2}{*}{$\begin{array}{l}\text { Volatile compounds } \\
\text { BC21 }\end{array}$} \\
\hline & & & $\mathrm{BC} 21$ & BCJ1 & $\mathrm{BCJ} 2$ & $\mathrm{BCJ} 3$ & BCJ4 & \\
\hline SJ4 & Bacillus safensis & OK562384 & $69.02 \pm 5.35 \Delta$ & $59.52 \pm 1.59 \triangle$ & $43.65 \pm 6.88 \triangle$ & $57.94 \pm 1.06 \triangle$ & $66.67 \pm 1.59 \triangle$ & $46.22 \pm 2.92 \Delta$ \\
\hline SJ19 & $\begin{array}{l}\text { Acinetobacter } \\
\text { calcoaceticus }\end{array}$ & OK562383 & $38.67 \pm 0.5 \Delta$ & $19.84 \pm 2.12 \Delta$ & $23.02 \pm 1.06 \triangle$ & $22.22 \pm 1.06 \Delta$ & $11.90 \pm 2.51 \Delta$ & $36.02 \pm 1 \triangle$ \\
\hline
\end{tabular}

Values represent the mean from three independently repeated experiments (each with three elementary replicates) \pm SE

${ }^{1}$ Within a column, $\Delta$ symbols indicate a significant difference between the values of each modality and the control as indicated by Newman-Keuls multiple range tests applied to the diameter values $(P<0.05)$

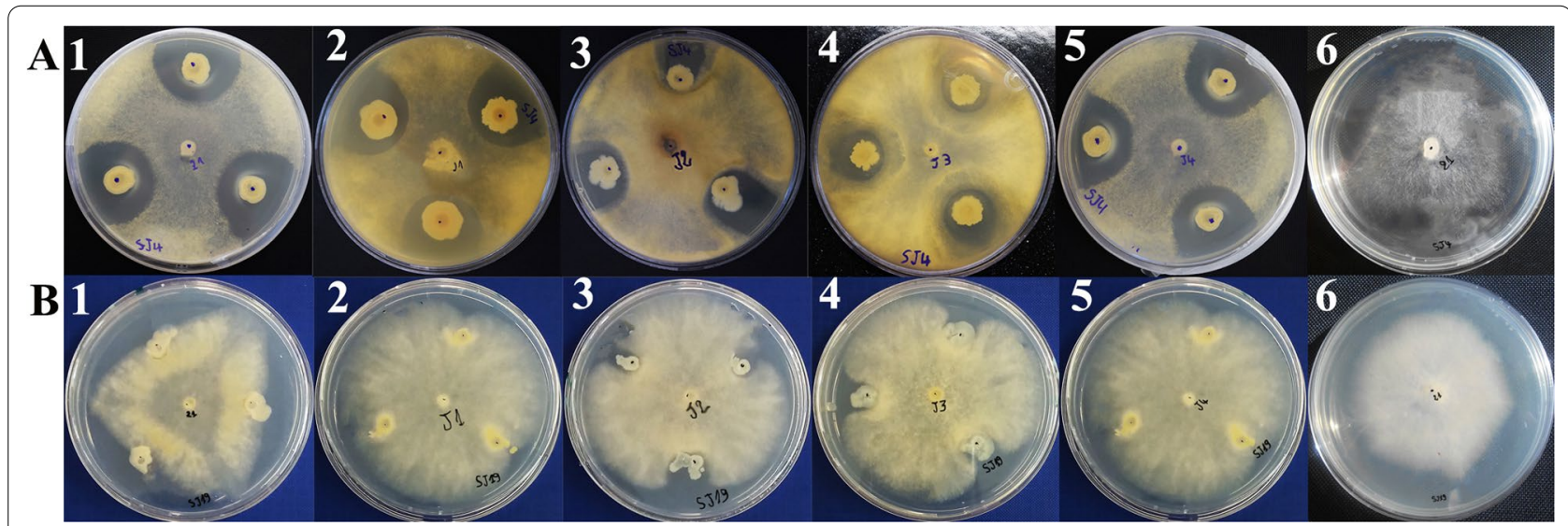

Fig. 1 In vitro effect of two bacterial isolates (SJ19 and SJ4) against various Botrytis cinerea strains. Tests were carried out at $22^{\circ} \mathrm{C}$ using PDA medium. The results of a direct in vitro effect are denoted by the letters $\mathbf{A} \mathbf{1 - A 5}$ for SJ4 and B1-B5 for SJ19. The indirect effects of SJ4 and SJ19 are denoted by $\mathbf{A} \mathbf{6}$ and $\mathbf{B} \mathbf{6}$, respectively. The numbers 1-5 represent, respectively, the fungal strains, $B C 21, B C J 1, B C J 2, B C J 3$ and $B C J 4$

of 43.7-69.0\%, isolate SJ4 showed a high level of inhibition against the strains of $B$. cinerea than isolate SJ19 (11.9-38.6\% inhibition).

\section{Indirect confrontation}

Both bacterial isolates significantly inhibited the mycelial growth of $B$. cinerea (strain $\mathrm{BC} 21$ ) through the production of volatile antifungal compounds (Newman-Keuls multiple range test; $P<0.05$ for SJ4 and SJ19) (Table 1 and Fig. 1). Isolate SJ4 provided significantly higher inhibition than SJ19.

\section{Protective effect of the bacteria on tomato plants}

On tomato plants, treating the wounds with the bacterial isolates immediately after inoculation resulted in a significant protective effect against $B$. cinerea (Fig. 2). With a protection index of $72.1 \%$, isolate SJ19 was significantly more efficient than SJ4 (52.3\%) (Newman-Keuls multiple range test; $P<0.05)$. The $1: 1$ combination of the two bacteria had the greatest protective effect $(87.8 \%)$, suggesting that these antagonists can work together to protect tomato plants against $B$. cinerea.
Applying the bacterial isolates on the wounds, one hour before or after inoculation with $B$. cinerea, also resulted in a significant protection (Fig. 2). The highest level of protection was observed, for both bacterial isolates, when the treatment was applied one hour before inoculation (Fig. 2).

\section{Plant growth-promoting effects of the bacterial isolates}

Soaking the tomato seeds in suspensions of the bacteria did not substantially alter their germination rate (MannWhitney test, $P=0.3$ for SJ4 and $P=0.072$ for SJ19), but the seed vigor index was increased by 52 and 23\%, respectively, by isolates SJ19 (Newman-Keuls multiple range test, $P<0.0001$ ) and SJ4 (Newman-Keuls multiple range test, $P=0.006$ ) (Fig. 3 ).

One month after the drench treatment of seedlings obtained from treated seeds, the plant growth indicators also showed a significant effect of the bacteria, in comparison with untreated controls. Treatments with isolate SJ19 significantly enhanced the lengths of roots and shoots by 99 and 43\%, respectively, than the untreated controls (Newman-Keuls multiple range test, $P<0.05$ ), 


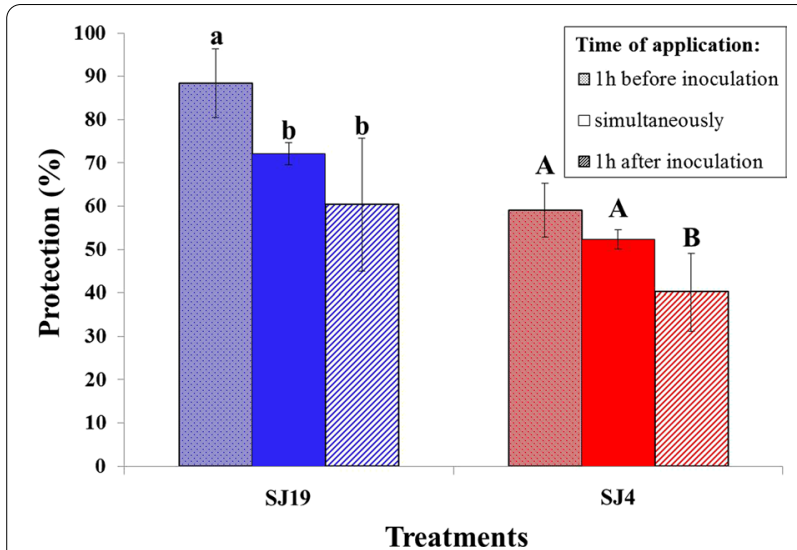

Fig. 2 Protective effect of two bacterial isolates (SJ19 and SJ4) on tomato plants against Botrytis cinerea. The bacteria were applied $1 \mathrm{~h}$ before ( 7 雨), simultaneously $(\square)$, or $1 \mathrm{~h}$ after $(\mathbb{Z})$ the inoculation with the pathogen (strain BC21). Six-week-old tomato plants (variety Clodano; Syngenta seeds, Switzerland) were used (five plants per modality). All treatments provided significant protection against the pathogen, compared to untreated control plants $(P<0.05)$. For a given bacterial strain, different letters above the bars indicate significant differences based on a Newman-Keuls multiple range test $(P<0.05)$ applied to the AUDPC values. Each value represents the mean from three independently repeated experiments \pm SE while isolate SJ4 increased these two parameters by 88 and $45 \%$, respectively (Newman-Keuls multiple range test, $P<0.05)$ (Fig. 4).

In addition, treatments with the bacteria significantly enhanced the fresh weight of shoots (Newman-Keuls multiple range test, $P<0.05$; Fig. 5). In comparison with the control plants, the fresh weight of shoots was increased by 102 and $83 \%$ and the roots by 69 and $58 \%$, respectively, by SJ19 and SJ4. The treatment of tomato seedlings with the bacteria also had a positive effect on stem diameter, number of leaves and chlorophyll content (Table 2).

\section{Pathogenicity and induction of hypersensitive response (HR)}

Following the application of the bacterial isolates on wounds of tomato plants, no disease symptoms were observed. Similarly, no necrosis or other symptoms were observed following their infiltration in leaves of tobacco plants.

\section{Discussion}

The present study provided evidence for the plant growth-promoting effect and for the biocontrol potential of two bacteria isolated from rhizospheric soil in Northern Algeria, which were identified as Acinetobacter calcoaceticus (isolate SJ19) and Bacillus safensis (isolate SJ4). The combination of in vitro and in planta experiments
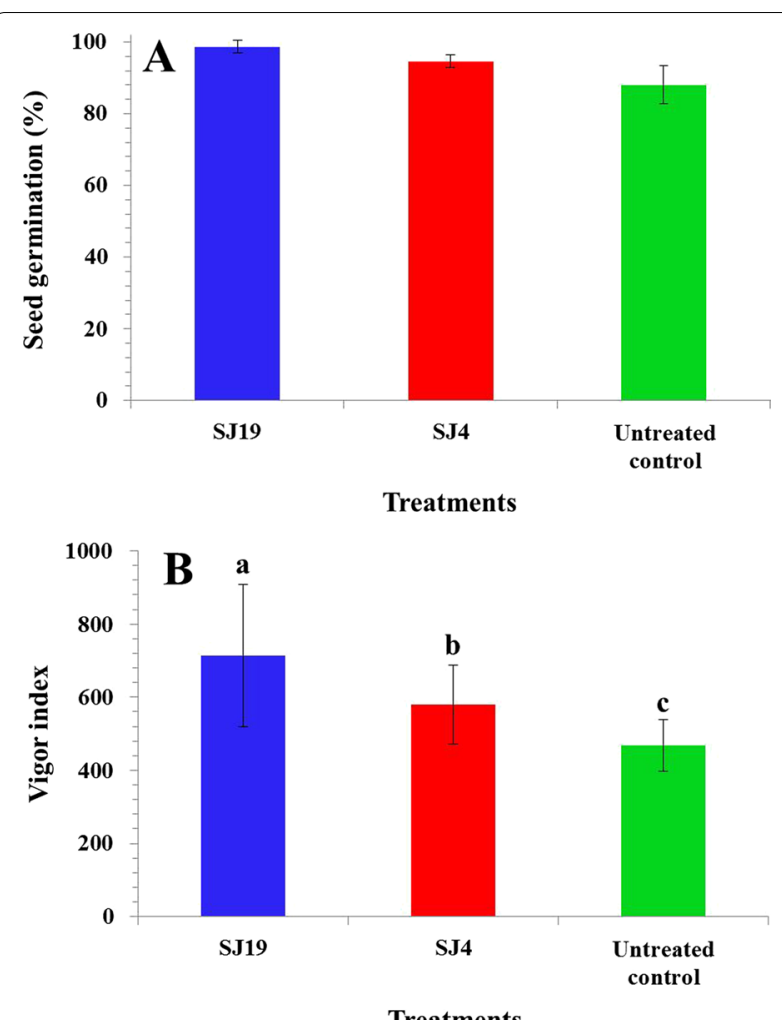

Treatments

Fig. 3 Effect of tomato seed treatments with two bacterial isolates on germination and seed vigor index. The treated seeds were soaked for $2 \mathrm{~h}$ in suspensions containing $10^{9} \mathrm{CFU} / \mathrm{ml}$, while the control seeds were soaked in sterile distilled water. Each value represents the mean from three independently repeated experiments \pm SE. There was no significant difference between treatments for seed germination $(P>0.05)$. For the seed vigor index, different letters above the bars indicate significant differences between treatments based on a Newman-Keuls multiple range test $(P<0.05)$. A presents the results of the percentage of tomato seed germination while $\mathbf{B}$ presents the results of Vigor Index

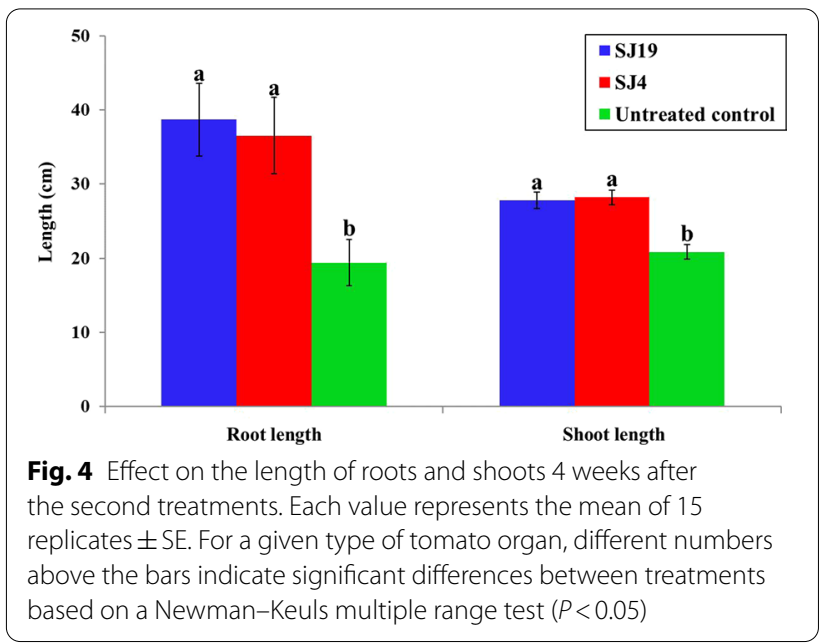




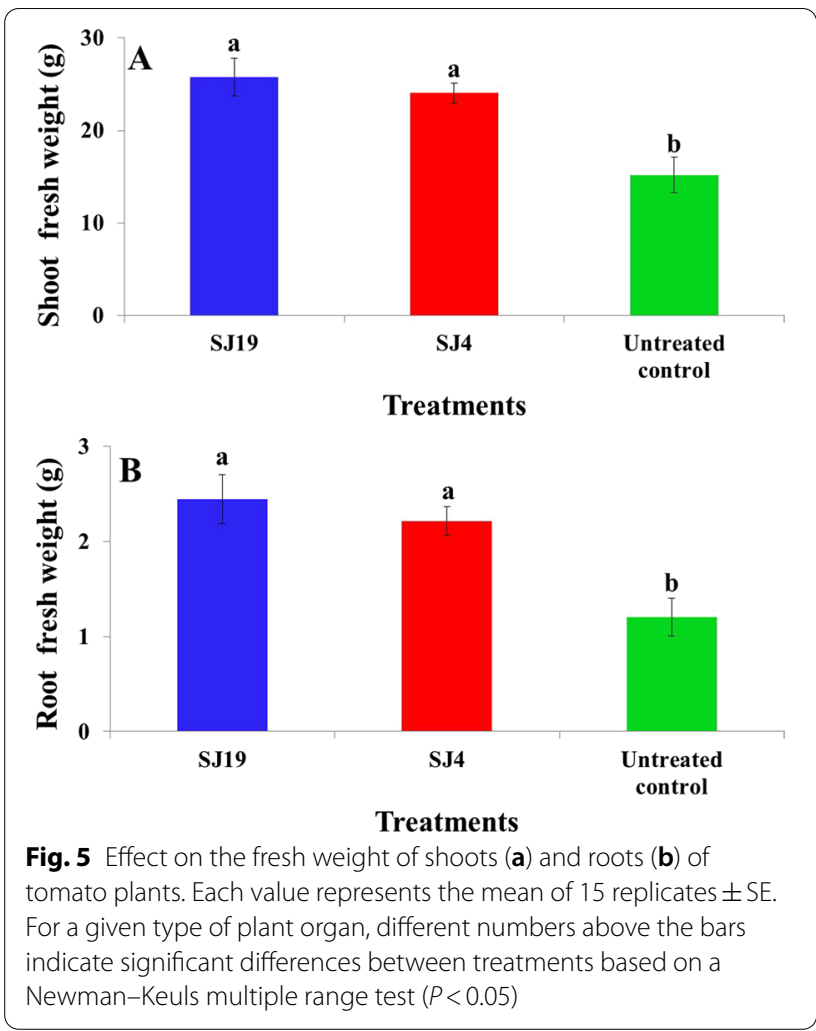

Table 2 Effect on stem diameter, chlorophyll content and number of leaves of tomato plants

\begin{tabular}{llll}
\hline Treatments & $\begin{array}{l}\text { Stem diameter } \\
(\mathbf{m m})\end{array}$ & $\begin{array}{l}\text { Chlorophyll } \\
\text { content } \\
\text { (SPAD) }\end{array}$ & Number of leaves \\
\hline Control & $6.8 \pm 0.24 \mathrm{~b}$ & $38.09 \pm 2.46 \mathrm{~b}$ & $5.6 \pm 0.48 \mathrm{~b}$ \\
SJ4 & $7.6 \pm 0.56 \mathrm{~b}$ & $43.71 \pm 1.27 \mathrm{a}$ & $7.2 \pm 0.32 \mathrm{a}$ \\
SJ19 & $8.3 \pm 0.24 \mathrm{a}$ & $44.97 \pm 1.60 \mathrm{a}$ & $7.2 \pm 0.32 \mathrm{a}$ \\
\hline
\end{tabular}

Values represent averages of 15 replicates \pm SE. Within a column, the same letters next to each value indicate that there is no significant difference as indicated by Newman-Keuls multiple range test $(P<0.05)$

carried out in the study also allowed to propose hypotheses on the possible mode of action implicated in the protection of tomato against one of its key pathogens, $B$. cinerea. In vitro assays showed that the mycelial growth of $B$. cinerea was significantly inhibited by the two isolates SJ4 and SJ19 with varying degrees of effectiveness. In accordance with the present results, several studies have reported the in vitro antagonistic effect of Bacillus (You et al. 2021) and Acinetobacter (Faria et al. 2021) species against a broad range of phytopathogenic fungi. Furthermore, species belonging to these two genera are known for producing diffusible and volatile antifungal compounds (You et al. 2021). Indeed, in the present study, SJ4 and SJ19 reduced the development of disease on tomato plants. Despite this, isolate SJ19 was not very effective against the pathogen in Petri plates. In line with these results, the efficacy of isolate SJ19 on plants suggested that it may suppress the disease by inducing plant resistance. This mechanism of action was shown by TrotelAziz et al. (2008) who revealed the capacity of two strains of Acinetobacter lwoffii that induced the plant defences against B. cinerea on grapevines. Bacillus species have also been found to stimulate plant defences against a wide range of diseases. Alamri et al. (2019) showed that B. subtilis HQ656002 was able to induce lettuce defence mechanisms against root rot caused by Exserohilum rostratum and Fusarium oxysporum. GTPase-activating protein, which played an important role in plant defence against pathogenic fungi, was identified, and the defensin genes were expressed in the presence of this bacterium. In fact, the influence of rhizospheric bacteria was demonstrated against a broad spectrum of tomato pathogens including fungi and bacteria (Zheng et al. 2019).

The present study provided results which could support the hypothesis that the tested isolates can induce defence mechanisms on tomato plants. The application of these isolates, one hour prior to the pathogen inoculation, improved their ability to protect tomato plants against $B$. cinerea, suggesting that these isolates can induce a defence reaction on tomato plants against the pathogen, and this mechanism of action was unable to express itself in vitro (at least for SJ19). According to Pascholati and Leite (1995), the time interval between the antagonist application and inoculation of the pathogen plays an important role in the protection induced by a biocontrol agent. For instance, in comparison with the curative treatment ( $24 \mathrm{~h}$ after pathogen inoculation), the preventive treatment ( $24 \mathrm{~h}$ before pathogen inoculation) with Bacillus amyloliquefaciens strain QST713 better protected bean plants against four mutants (among six mutants tested) of B. cinerea (Samaras et al. 2021).

In the present study, a synergistic effect of SJ4 and SJ19 was recorded. The mixture of the two antagonists enhanced the protective effect against $B$. cinerea on tomato plants. The results are consistent with those of other research showing that combining multiple PGPRs can improve their biocontrol potential (Sharma et al. 2018). In general, PGPR mixtures employed as biocontrol agents have the advantage of being able to combine their multiple traits, especially those that are difficult to find in a single bacterium. This distinguishing characteristic plays a critical role in enhancing the effectiveness and reliability of disease control (Wang et al. 2021).

SJ19 and SJ4 isolates significantly promoted the growth of tomato plants by increasing seed vigor index, number of leaves, stem diameter, contents of chlorophyll, length 
of roots and shoots and plants fresh weight. Other studies have found similar results (Alamri et al. 2019). Indeed, the tested Acinetobacter and Bacillus species are known as power PGPRs enhancing plant growth including tomatoes (Mohamed et al. 2020). The PGP effect depended on the inoculation method. Xue et al. (2009) showed that the inoculation of Acinetobacter sp. strain Xa6 by drenching method promoted tomato growth better than the damping method. Besides, the ability of Acinetobacter and Bacillus species and the other PGPRs to promote plants growth is often assured by the synthesis of certain secondary metabolites.

\section{Conclusions}

In conclusion, the present study highlights the capacity of two rhizospheric bacteria (SJ4 and SJ19) to protect tomato plants against B. cinerea. B. safensis strain SJ4 and Acinetobacter calcoaceticus strain SJ19 also promoted the growth of tomato plants. These encouraging findings could be the first step towards using these two bacteria in the field as bio-fungicidal agents to control grey mould and biofertilizers to promote plants growth. Nevertheless, additional research appears to be required to understand the behaviour of these bacteria in the environment.

\begin{abstract}
Abbreviations
AUDPC: Area under the disease progress curve; CFU: Colony-forming unit; HR: Hypersensitive response; NCBI: National Center for Biotechnology Information; PDA: Potato dextrose agar; PGPR: Plant growth-promoting rhizobacteria; $\mathrm{RH}$ : Relative humidity.
\end{abstract}

\section{Acknowledgements \\ We gratefully acknowledge the Ministry of Higher Education and Scientific Research of Algeria for the scholarship awarded to Abdelhamid Foughalia. Thanks are also due to Magali Eygrier, Magali Duffaud, Jean-François Bourgeay and Claire Troulet for their invaluable assistance during this work. We are indebted to Nathalie Truglio, Joël Beraud and Jéremy Theodore for their help in preparing and growing the tomato plants that were used in this study.}

\section{Authors' contributions}

AF involved in the sampling and isolation of bacteria and fungi, and the writing of the manuscript. This research is part of his doctoral thesis project. YB contributed to the in vitro tests and the identification of $B$. cinerea strains. CC involved in the molecular characterization of bacteria. MD prepared culture media and conserved the bacteria and the fungal strains. MT is a plant pathologist; he was involved in the detection of grey mould on tomato plants and carried out pathogenicity tests of $B$. cinerea on tomato plants. KA revised the article. He is the co-supervisor of AF PhD. PN supervised the study of AF PhD and revised the article. All authors read and approved the final manuscript.

\section{Funding}

This study was funded by the Ministry of Higher Education and Scientific Research of Algeria through scholarship awarded to Abdelhamid Foughalia.

\section{Availability of data and materials}

We confirm the availability of all the data included in this study.

\section{Declarations}

Ethics approval and consent to participate Not applicable.
Consent for publication

Not applicable.

\section{Competing interests}

The corresponding author declares that there are no competing interests on behalf of all authors.

\section{Author details}

${ }^{1}$ Laboratoire de Génétique, Biotechnologie et Valorisation des Bio-Ressources (GBVB), Faculté des Sciences Exactes et des Sciences de la Nature et de la Vie, Université Mohamed Khider, Biskra, Algeria. ${ }^{2}$ Centre for Scientific and Technical Research on Arid Regions, Biskra, Algeria. ${ }^{3}$ Laboratoire d'écologie Microbienne, Faculté des Sciences de la Nature et de la Vie, Université Abderrahmane Mira, 06000 Bejaia, Algeria. ${ }^{4}$ Plant Pathology, INRAE, 84140 Montfavet, France. ${ }^{5}$ Université Mostefa Benboulaid, Batna 2, Algeria.

Received: 8 November 2021 Accepted: 31 January 2022

Published online: 08 February 2022

\section{References}

Aissat K, Nicot PC, Guechi A, Bardin M, Chibane M (2008) Grey mould development in greenhouse tomatoes under drip and furrow irrigation. Agron Sustain Dev 28:403-409. https://doi.org/10.1051/agro:2008016

Akter S, Jo H, Du J, Won K, Yin CS, Kook MC, Yu H, Choi HS, Kim MK, Yi TH (2015) Pseudoxanthomonas humi sp. nov., a bacterium isolated from rhizospheric soil of Fraxinus chinensis in Gyeonggi Province. South Korea Arch Microbiol 197:1165-1172. https://doi.org/10.1007/s00203-015-1157-5

Alamri SAM, Hashem M, Mostafa YS, Nafadyb NA, Abo-Elyousr KAM (2019) Biological control of root rot in lettuce caused by Exserohilum rostratum and Fusarium oxysporum via induction of the defense mechanism. Biol Control 128:76-84. https://doi.org/10.1016/j.biocontrol.2018.09.014

Anonymous (2017) Index des produits phytosanitaires à usage agricole. Ministère de l'Agriculture, du Développement rural et de la Pêche. Direction de la protection des végétaux et des contrôles techniques. République Algérienne Démocratique et Populaire

Barakat FM, Abada KA, Abou-Zeid NM, El-Gammal YHE (2014) Effect of volatile and non-volatile compounds of Trichoderma spp. on Botrytis fabae the causative agent of faba bean chocolate spot. Am J Life Sci 2(6-2):11-18. https://doi.org/10.11648/j.ajls.s.2014020602.12

Bouaoud Y, Troulet C, Foughalia A, Berge O, Bardin AK, M, (2018) A multicriteria approach for the selection of efficient biocontrol agents against Botrytis cinerea on tomato in Algeria. Biocontrol 63:299-311. https://doi. org/10.1007/s10526-017-9851-7

Boukaya N, Goudjal Y, Zamoum M, Chaabane FC, Sabaou N, Mathieu F, Zitouni A (2018) Biocontrol and plant-growth-promoting capacities of actinobacterial strains from the Algerian Sahara and characterization of Streptosporangium becharense SG 1 as a promising biocontrol agent. Biocontrol Sci Tech 28(9):858-873. https://doi.org/10.1080/09583157.2018.1501466

Decognet V, Bardin M, Trottin-Caudal Y, Nicot PC (2009) Rapid change in the genetic diversity of Botrytis cinerea populations after the introduction of strains in a tomato glasshouse. Phytopathology 99(2):185-193. https:// doi.org/10.1094/PHYTO-99-2-0185

Faria PSA, Marques VO, Selari PJRG, Martins PF, Silva FG, Sales JF (2021) Multifunctional potential of endophytic bacteria from Anacardium othonianum Rizzini in promoting in vitro and ex vitro plant growth. Microbiol Res 242:126600. https://doi.org/10.1016/j.micres.2020.126600

Liu S, Fu L, Tan H, Jiang J, Che Z, Tian Y, Chen G (2021) Resistance to boscalid in Botrytis Cinerea from greenhouse-grown tomato. Plant Dis. https://doi. org/10.1094/PDIS-06-20-1191-RE

Mohamed BFF, Sallam NMA, Alamri SAM, Abo-Elyousr KAM, Mostafa YS, Hashem M (2020) Approving the biocontrol method of potato wilt caused by Ralstonia solanacearum (Smith) using Enterobacter cloacae PS14 and Trichoderma asperellum T34. Egypt J Biol Pest Control 30:61. https://doi.org/10.1186/s41938-020-00262-9

Morris CE, Sands DC, Vanneste JL, Montarry J, Oakley B, Guilbaud C, Glaux C (2010) Inferring the evolutionary history of the plant pathogen Pseudomonas syringae from its biogeography in headwaters of rivers in North America Europe and New Zealand. mBio 1:1-11. https://doi.org/10.1128/ mBio.00107-10 
Panno S, Davino S, Caruso AG, Bertacca S, Crnogorac A, Mandić A, Noris E, Matić SA (2021) Review of the most common and economically important diseases that undermine the cultivation of tomato crop in the Mediterranean basin. Agronomy 11:2188. https://doi.org/10.3390/agron omy11112188

Pascholati SF, Leite B (1995) Hospedeiro: mecanismo de resistência. In: Bergamin FA, Kimati H, Amorim VJ, Szilagyi-Zecchin et al. (ed) Manual de fitopatologia princípios e conceitos. 1st edn. Agronômica Ceres, São Paulo

Samaras A, Hadjipetrou C, Karaoglanidis G (2021) Bacillus amyloliquefaciens strain QST713 may contribute to the management of SDHIs resistance in Botrytis cinerea. Pest Manag Sci. https://doi.org/10.1002/ps.6145

Sharma CK, Vishnoi VK, Dubey RC, Maheshwari DK (2018) A twin rhizospheric bacterial consortium induces systemic resistance to a phytopathogen Macrophomina phaseolina in mung bean. Rhizosphere 5:71-75. https:// doi.org/10.1016/j.rhisph.2018.01.001

Syed-Abd-Rahman SF, Carvalhais LC, Schenk P (2018) Identification of soil bacterial isolates suppressing different Phytophthora spp. and promoting plant growth. Front Plant Sci 9:1-9. https://doi.org/10.3389/fpls.2018. 01502

Trotel-Aziz P, Couderchet M, Biagianti S, Aziz A (2008) Characterization of new bacterial biocontrol agents Acinetobacter, Bacillus, Pantoea and Pseudomonas spp. mediating grapevine resistance against Botrytis cinerea. Environ Exp Bot 64:21-32. https://doi.org/10.1016/j.envexpbot.2007.12. 009

Walia A, Putatunda C, Sharma R, Sharma S, Thakur A (2021) Biocontrol: a sustainable agricultural solution for management of plant diseases. In: Kaushal M, Prasad R (eds) Microbial biotechnology in crop protection. Springer, Bihar

Wang H, Liu R, You MP, Barbetti MJ, Chen Y (2021) Pathogen biocontrol using plant growth-promoting bacteria (PGPR): role of bacterial diversity. Microorganisms 9:1988. https://doi.org/10.3390/microorganisms9091988

Whipps JM (1987) Effect of media on growth and interactions between a range of soil-borne glasshouse pathogens and antagonistic fungi. New Phytol 107:127-142. https://doi.org/10.1111/j.1469-8137.1987.tb04887.x

Xu S, Kim BS (2014) Biocontrol of Fusarium crown and root rot and promotion of growth of tomato by Paenibacillus strains isolated from soil. Mycobiology 42(2):158-166. https://doi.org/10.5941/MYCO.2014.42.2.158

Xue QY, Chen Yu, Li SM, Chen LF, Ding GC, Guo DW, Guo JH (2009) Evaluation of the strains of Acinetobacter and Enterobacter as potential biocontrol agents against Ralstonia wilt of tomato. Biol Control 48:252-258. https:// doi.org/10.1016/j.biocontrol.2008.11.004

You W, Ge C, Jiang Z, Chen M, Wen Li, Shao Y (2021) Screening of a broadspectrum antagonist-Bacillus siamensis, and its possible mechanisms to control postharvest disease in tropical fruits. Biol Control 157:104584. https://doi.org/10.1016/j.biocontrol.2021.104584

Zheng X, Wang J, Chen Z, Zhang H, Wang Z, Zhu Y, Liu B (2019) A Streptomyces sp. strain: Isolation, identification, and potential as a biocontrol agent against soilborne diseases of tomato plants. Biological Control 136:104004. https://doi.org/10.1016/j.biocontrol.2019.104004

\section{Publisher's Note}

Springer Nature remains neutral with regard to jurisdictional claims in published maps and institutional affiliations.

\section{Submit your manuscript to a SpringerOpen ${ }^{\circ}$ journal and benefit from:}

- Convenient online submission

- Rigorous peer review

- Open access: articles freely available online

- High visibility within the field

- Retaining the copyright to your article

Submit your next manuscript at $\boldsymbol{\nabla}$ springeropen.com 